\title{
Miranda
}

Revue pluridisciplinaire du monde anglophone /

Multidisciplinary peer-reviewed journal on the English-

speaking world

$8 \mid 2013$

In Umbra Voluptatis : Shades, Shadows, and their

Felicities / Film Adaptations, New Interactions

\section{Kate Flint, ed., The Cambridge History of Victorian \\ Literature}

Laurence Talairach-Vielmas

\section{OpenEdition}

Journals

Electronic version

URL: http://journals.openedition.org/miranda/3379

DOI: $10.4000 /$ miranda.3379

ISSN: 2108-6559

Publisher

Université Toulouse - Jean Jaurès

Electronic reference

Laurence Talairach-Vielmas, "Kate Flint, ed., The Cambridge History of Victorian Literature", Miranda [Online], 8 | 2013, Online since 28 June 2013, connection on 16 February 2021. URL: http:// journals.openedition.org/miranda/3379; DOI: https://doi.org/10.4000/miranda.3379

This text was automatically generated on 16 February 2021

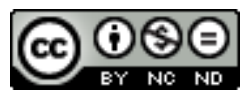

Miranda is licensed under a Creative Commons Attribution-NonCommercial-NoDerivatives 4.0 International License. 


\title{
Kate Flint, ed., The Cambridge History of Victorian Literature
}

\author{
Laurence Talairach-Vielmas
}

\section{REFERENCES}

Kate Flint, ed., The Cambridge History of Victorian Literature (Cambridge: Cambridge University Press, 2012), 774 p, ISBN 978-0-521-84625-7

Divided into six main sections, The Cambridge History of Victorian Literature, edited by Kate Flint, proposes a journey into the culture that shaped Victorian literature. The kaleidoscopic presentation of the period, its concerns, changes or discoveries aims to define literature as a significant cultural product that cannot be separated from and must be investigated in context. It shows how, from the first decades of the nineteenth to the fin de siècle, the Victorians were not only confronted with the theory of evolution but also with new technologies, different cultures and peoples which informed and inflected the writing of the period. Furthermore, "things" were everywhere in the Victorian booming consumer society which liked to put everything on display, consumers collecting objects as naturalists collected specimens. The 33 chapters thus cover the main issues of the period, relating them to literary genres, modes and writers.

Parts 1, 2 and 3 look at authors, readers and publishers (part 1), writing practices and the different modes of writing of the period (ranging from the lyrical (Angela Leighton) and the epic (Herbert F. Tucker) to melodrama (Carolyn Williams) and sensation (Kate Flint), and even focussing on children's literature (Claudia Nelson) and autobiography (Linda H. Peterson) (parts 2 and 3)). The contributors constantly relate Victorian literature to the material reality of the production of books (revolutionized by the steam-powered printing machine) at a time when the expansion of the reading public and the growth of "niche markets" enabled the development of various genres and subgenres. The ways in which the changes in the production and distribution of texts 
impacted the literature of the time can also be seen in the growing use of images and the shift in the relationship between text and image, while fiction was inserted everywhere, dramatically modifying the status of writers and their economic fortunes (David Finkelstein). Moreover, the changes in readership and reading practices gave rise to anxieties concerning types of reading (active/passive) and the role of literature as a civilizing medium.

The book also highlights the connections between Victorian literature and key issues of the time (part 4). Education (Dinah Birch), the changes in an economic system based upon speculation and the "financialization of culture" (Mary Poovey, 389), sexuality (Sharon Marcus) or spirituality (Elisabeth Jay) are some of the themes that are tackled. Several chapters show how evolutionary explanations of humans' origin challenged Victorian religion and altered the vision and definition of "nature" (Francis O'Gorman), while the Industrial Revolution and massive urbanisation, transfiguring the rural landscape, gave rise to "Cityscapes" (Deborah Epstein Nord). Stereotypical oversimplifications are avoided (for example, by reminding readers that the literary response to evolutionary theory preceded the publication of Darwin's Origin of Species in 1859 (Gillian Beer)), and some chapters stress that natural selection was not the only scientific argument that was disseminated in literary works. The evolution of scientific methods, with, for instance, the rise of scientific experimentation, informed the literature of the period as well, while Victorian writers' knowledge of the developments in psychology and psychiatric medicine (such as Charlotte Brontë, George Eliot, Lord Alfred Tennyson, Wilkie Collins, Edward Bulwer Lytton, William Makepeace Thackeray, Elizabeth Gaskell, George Meredith, Walter Pater, Oscar Wilde, to name but a few) engaged in "a reformist spirit", particularly obvious in the rise of sensation fiction in the 1860s, the genre's "neuro-physiological conception of the reading process" (Helen Small, 499) striking the reviewers of the time. Many chapters show how scientific ideas were made accessible to a large audience, explaining their cultural assimilation (and here again the changes in the production of books and their impact on the popularisation of science must be highlighted). However, as Gillian Beer underlines, scientists had recourse to literature (especially poetry) not only to communicate with their public by using a language and references they were familiar with ; literature also secured the connection of the past and the present, playing a key role in "assuag[ing] the anxieties in the face of the New" (470). Thus, if the relations between literature and science were often heated in the period, literature was not simply a mode of diffusion of contemporary debates or discoveries but also a crucial resource for scientists. The part that literature played in the shaping of scientific knowledge is therefore brought to light, while the use of scientific language (related, for example, to the fields of anatomy or what we now call biology), as well as the language of technology, were not simply used in metaphorical ways in the literature of the period, as Clare Pettitt contends. The Victorian culture was "technologically embedded" (Clare Pettitt, 551), and genres such as the industrial novel, the sensation novel or the detective novel in the last decades of the century typify the relationship between technology and the culture of modernity, since they question problems related to speed or globalization and often bring to light a "machine culture" (560). In many of the issues explored in parts 4 and even 5, the sensation novel (represented by writers such as Mary Elizabeth Braddon, Wilkie Collins, Mrs Henry Wood or Charles Reade) is time and again used as a key example, bringing to the fore many of the evils of the age and disseminating new definitions of society, the mind, the body (as mediated by technology), or reflecting the 
impact of technology on writing (from the genre's relationship with the popular press and sensational cases to the references to optical technology in narratives pivoting upon photographs, for example).

4 Part 5, entitled "Spaces of writing", looks at space in the nineteenth century and chronotopes found in the Victorian novel (Isobel Armstrong), and examines representations of national and regional literatures (Sara L. Maurer), Europe (Nicholas Dames), the Empire (Pablo Mukherjee) or America (Deidre David). The book closes on 1900 and the début de siècle (Joseph Bristow) and poses the question of the future of Victorian literature (Jay Clayton). It is followed by a select bibliography for each of the 33 chapters, which will enable students of the period to further their knowledge of Victorian studies. Although it is a difficult task to summarize such a comprehensive study of Victorian literature in context, it stands to reason that this Cambridge History will undeniably be an essential guide to understand what Victorian literature was exactly.

\section{INDEX}

Keywords: Victorian literature, Victorian culture, literature and science, technology

Mots-clés: littérature victorienne, culture victorienne, littérature et science, technologie

\section{AUTHORS}

\section{LAURENCE TALAIRACH-VIELMAS}

Université de Toulouse-Le Mirail

Professeur des Universités

talairac@univ-tlse2.fr 